\title{
ASPECTS REGARDING THE PROMOTION OF MOVEMENT GAMES THROUGH THE STRUCTURAL COMPONENTS OF THE MIDDLE SCHOOL PHYSICAL EDUCATION LESSON
}

\author{
Dobrescu Tatiana ${ }^{1 *}$ \\ 1 "Vasile Alecsandri" University of Bacău, 157, Calea Marasesti, Romana
}

Keywords: movement game, lesson structure, use, middle school

\begin{abstract}
The aim of this paper was to highlight the promotion degree of movement games in middle school education, by looking at its use in the structural component of the physical education lesson. In order to capture various aspects regarding the use of movement games in the physical education lesson, 40 observation charts were made for the lessons conducted at two Bacau schools. Following the results recorded during the studied physical education lessons, and based on the observation charts, it can be said that the use of movement games did not record impressive values, and their formative value has not been exploited at its full potential. That is why one can say that the physical education teachers should make more use of their imagination and creativity in using these means during their lesson.
\end{abstract}

\section{Introduction}

Under current conditions of restructure of the entire educational process and reposition it on democratic bases, an improvement is needed of the instructive-educational process, in all subjects, physical education included, in regards to both the contents and the means and methods that are used. It is necessary for active methods to be used during physical education lessons, allowing the pupils the opportunity to actively participate in the training process.

Of the diversity of means that are at the teacher's disposal, the movement game is one of the most attractive solutions for stimulating the pupils to exercise. Being subordinated to the instructional objectives, through its contents and rules, the movement game is also a means and a method that needs to be promoted in the structure of the physical education lesson.

The movement game is different from other physical education means because it eases the learning and internalization of motor skills in ever changing situations (Acsinte, 2006), the competition element presupposing efforts for accomplishing tasks successfully, which allows for the development of both the

\footnotetext{
*E-mail: tatianadobrescu2002@yahoo.com
} 
motor and moral qualities of the pupils (Bonta, 2003).

This research was chosen starting from the consideration that the form, content, and beneficial effects of the movement game are mostly advantageous for middle school pupils.

Starting from the belief that the promotion of movement games in the structure of the physical education lesson is a sine qua non condition for accomplishing the objectives of the middle school curricula, in an attractive and accessible way (Raţă \& Rață, 2008), one can create the motivational premises for attracting the pupils toward physical exercise.

\section{Material and methods}

The aim of this paper was to highlight the promotion degree of movement games in middle school education, by looking at its use in the structural component of the physical education lesson.

This study started from the following hypotheses:

- Presumably, the movement game is an accessible means for the physical education teachers to accomplish the objectives of the middle school physical education lesson.

- The identification of how much the movement game is used in the structure of the middle school physical education lesson constitutes a premise for an applicative intervention regarding the improvement of the instructional process.

The research was conducted throughout the academic year of 2014-2015. In order to capture various aspects regarding the use of movement games in the physical education lesson, 40 observation charts were made for the lessons conducted at two Bacau schools: the "A.I. Cuza" School no. 19, and School no. 10 of Bacau, for grades 5-6.

The observational research was conducted between January and May, 2015, capturing the very diverse elements of the lesson plans.

The observations envisaged the identification of movement games as means to put into practice the curricular contents and accomplishing the objectives of the middle school physical education lessons. These observations studied how much these means are used by the middle school teachers. (Raţă, 2008).

It has to be mentioned the fact that the observations did not consider other types of games with particularized rules, such as school games or theme games, or any other means, such as applicative tracks.

The observation chart comprised specific middle school curricular contents, movement games that were selected after studying the bibliographical materials, which were inserted on the vertical axis. In the structure of the instruments used in this research, the structural components of the physical education lesson were inserted on the horizontal axis, and at the intersection of the two axes, the recorded data was inserted, which was the number of recorded lessons and the corresponding percentage.

Professional literature highlights various ways to use movement games for the accomplishment of every middle school physical education lesson objective. 
(Buscher, 2000, Pieper, 2001). They can be used successfully in most structural components of the lesson, according to its objectives. "They contribute to the creation of a good working disposition, to cheering up the group, both from a physical and a psychological point of view, as well as to the training of certain moral and physical qualities" (Băieşu \& Bârlea, quoted Dobrescu \& Constantinescu, 2006).

\section{Results and Discussions}

Following the observations made in the two schools, it was noticed that over the course of the study, 45 forms of these means were recorded in School 10, with 0,25 more in average than what was recorded in School 19.

After analyzing the use of movement games during the lessons, one can see that in the first two parts of the lesson the teachers used, for the organization of the pupils, and especially for warm-up, attention games (20\%), reverse command games (7.5\%), games for developing the pupils' perception skills (12.5\%), and games for developing the pupils' relation with objects (10\%).

Even though no movement game was used for the development of the musculoskeletal system, during the sets of physical development exercises there were game elements that have stimulated the pupils' emulation for correct performances, with an increased range of motion and a good localization of the motions.

The education / motor skills development parts benefited from a great variety of movement games. They were used mainly for the development of speed (17.5\%), dexterity (22.5\%), strength (17.5\%), and to a lesser extent, endurance (10\%).

Another structural component of the lesson in which the teachers used dynamic means was the part regarding the learning and internalization of applicative skills (12.5\%), of track and field motor content (17.5\%), gymnastics (20\%), and team games (37.5\%).

In many lessons with themes envisaging the development of skills that are specific to certain sports, the teachers used exercises from track and field, gymnastics, team sports, or other types of games, such as the ones with a theme, school games, bilateral games, as well as applicative tracks.

The cooling-down was done through simple games, of small intensity and recreational in nature, such as attention games and reverse command games (12.5\%).

At the end of the observational research one can see that the games used during the lessons were not very complex, did not involve in all cases the use of objects, devices, or special arrangements. However, one can emphasize the emulation spirit that was applied in most cases and the specifications regarding the respect for the rules.

In order to highlight how much the movement games were used during the middle school physical education lesson, a comparative analysis has been performed for the results from the two researched groups. (Fig. 1) 


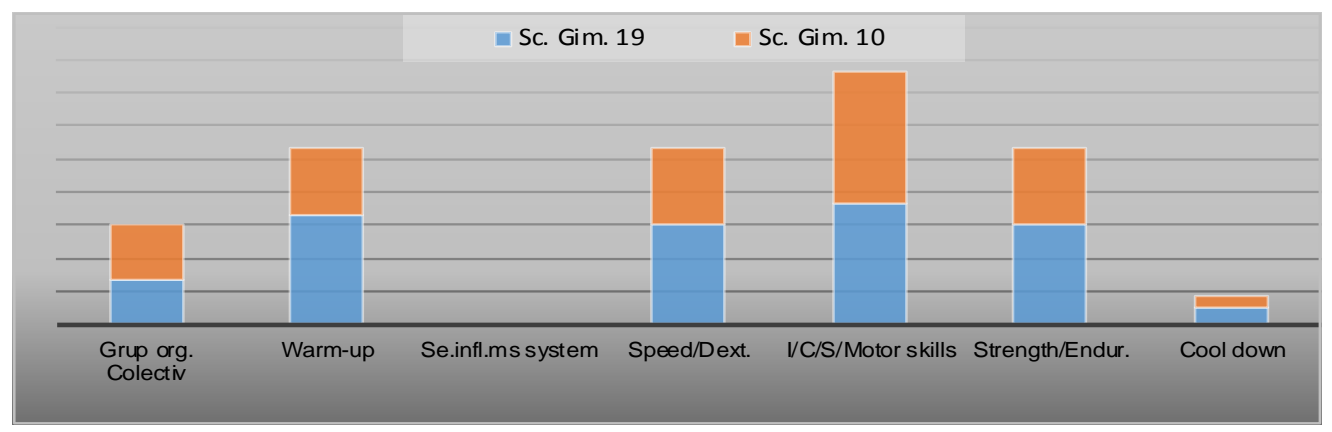

Figure 1. The use of movement games in the lesson structure

During the preparing part of the lesson, the teachers used attentiongrabbing games, inciting games, and spatial orientation games, with an easier and gradual effort engagement.

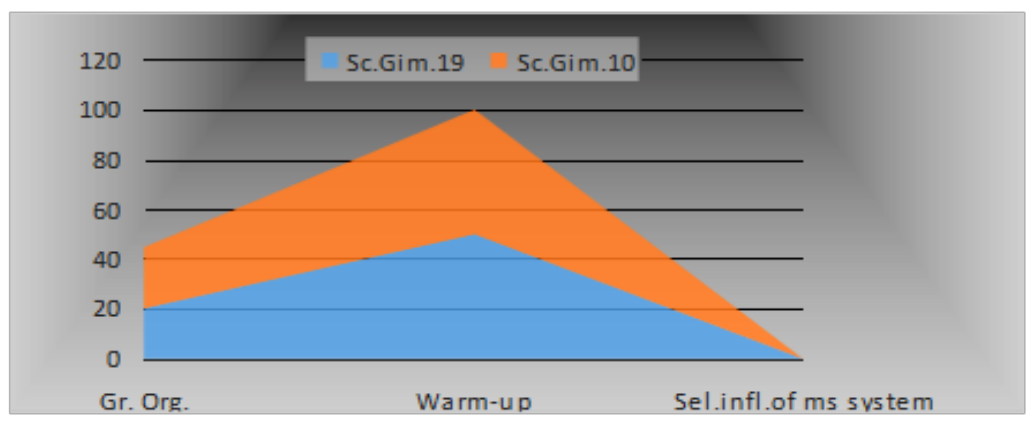

Figure 2. Results of the observations for the first 3 parts of the lesson

If in both schools, the teachers used in $50 \%$ of the recorded lessons movement games for the warm-up, during the first part for organizing the group of pupils, School 10 used 5\% more movement games. (Fig. 2)

In the fundamental part, the games that were chosen have led to the accomplishment of the tasks in this part, forming or internalizing the basic motor skills that are specific to certain sports, contributing to the education of sensitivity (rhythm, balance) and pf basic motor skills (speed, dexterity, strength and endurance). In some lessons with themes envisaging the learning / internalization of skills that are specific to certain sports, the teachers used exercises from track and field, gymnastics, team sports, or other types of games, such as the ones with a theme, school games, bilateral games, applicative tracks.

After analyzing how much the movement games were used for the learning / internalization / assessment of various sports skills, one can see that if in regards to the gymnastics skills, both schools manifested an equal interest (20\%), the first school used more team sports elements (25\%/15\%), while for the track and field elements, it was the other way round (10\%/25\%) (Fig. 3). 


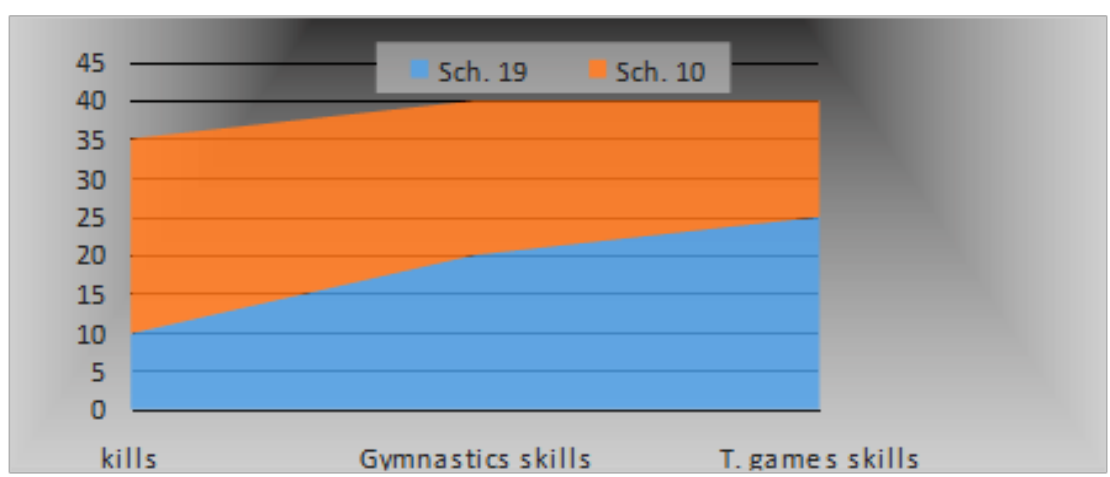

Figure 3 Results of the observations for the parts that are specific to certain sports

Also in this part of the lesson one can highlight the preoccupation of the teachers in both schools for attaining the objectives regarding the development of psycho-motor skills. School 19 used movement games mostly for developing the dexterity (35\%) and strength (30\%), while School 10 used them mostly for the development of speed (25\%) and strength (30\%). Both schools opted to use specific sports means for the development of endurance. (Fig. 4)

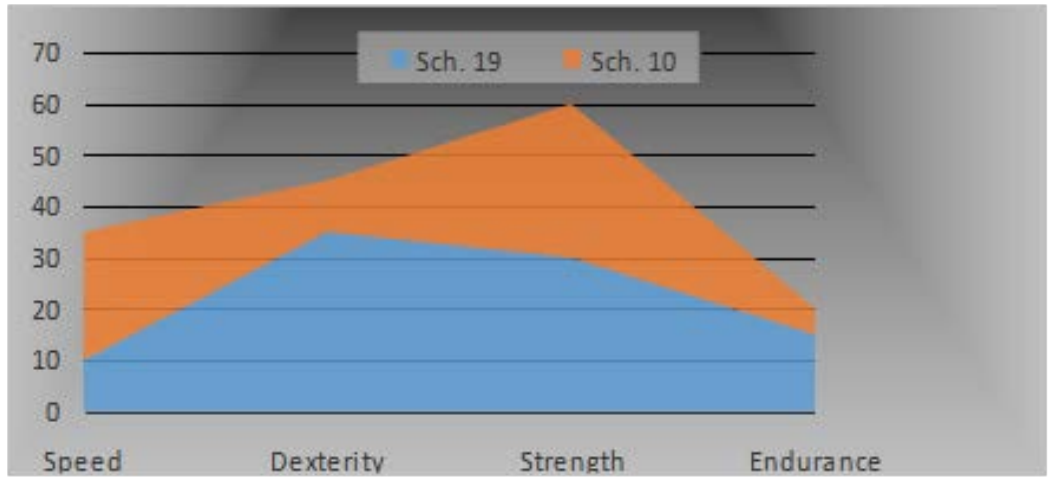

Figure 4 Results of the observations for the parts of motor skill development

In both schools, the teachers did not use relaxing games that would reestablish the higher functions and to capture the pupils' attention during the closing part of the physical education lessons.

\section{Conclusions}

Following the observations and the results recorded in the observation charts, the following conclusions can be drawn:

1. Movement games are an important and accessible means for the physical education teachers to accomplish an important part of the physical education tasks, aiming to improve their lesson, which confirms the first hypothesis. 
2. Through the judicious application of the movement games, there is a possibility to greatly contribute to the development of the motor skills (speed, endurance, strength, and dexterity) that are useful in life, teaching useful knowledge, by enlarging the children's sphere of representations of the world.

3. During movement games, the competition element in most cases presupposes effort to complete successfully the actions, which allows the development of team spirit, moral and volitional qualities.

4. The difficulties encountered by pupils in games containing jumps over exercise equipments develop their willpower, their perseverance and, when these difficulties are overcome, their self-confidence.

6. The increase of the effectiveness of the physical education lesson can be done through the use of movement games, if they are well selected, organized and tactfully managed by the teacher.

7. Following the results recorded during the studied physical education lessons, and based on the observation charts, it can be said that the use of movement games did not record impressive values, and their formative value has not been exploited at its full potential. That is why one can say that the physical education teachers should make more use of their imagination and creativity in using these means during their lesson.

8. The second hypothesis was confirmed through the identification of how much the movement games were used as a method and means for grades 5-6, and it created the premises for an applicative intervention that would emphasize the diverse influences these games have on the pupils, and the various ways to improve the middle school physical education lesson.

\section{References}

1. ACSINTE A. (2006). Activităţi de timp liber, jocuri dinamice, Iaşi: Editura Performantica, Romania;

2. BONTA, E. (2003). Conversaţia între joc şi jocuri, Studii şi cercetări ştiinţifice, Seria: Ştiinţe socio-umane, Psihologie - Ştiinţele educaţiei didactică, 92-102, D. P. P. D., Universitatea Bacău, Romania;

3. BUSCHER, N. (2000). Le jeu une foction riche de sens. De l'homo sapiens a l'homo ludens, Rev. Mobile, 4, 21, Paris, France;

4. DOBRESCU T., CONSTANTINESCU E. (2006). Gimnastica - concepte teoretice şi aplicaţii practice, Iaşi: Editura Tehnopress, Romania;

5. PIEPER, A. (2001). La vie n'est qu'un grand jeu !, Rev. Mobile, 2, 8, Paris, France;

6. RATA G. (2008). Didactica educaţiei fizice şi sportului, Editura "PIM”, Iaşi.

7. RAŢĂ G, RAȚĂ Ghe. (2008). Educaţia fizică şi metodica predării ei, Iaşi: Editura "PIM", Romania. 


\title{
ASPECTE PRIVIND PROMOVAREA JOCURILOR DE MIȘCARE DIN PRISMA COMPONENTELOR STRUCTURALE ALE LECTIIEI DE EDUCAȚIE FIZICĂ LA CICLUL GIMNAZIAL
}

\author{
Dobrescu Tatiana ${ }^{1}$ \\ 1Universitatea "Vasile Alecsandri" din Bacău, Calea Mărășești nr. 157, România
}

Cuvinte cheie: movement game, lesson structure, use, middle school

\section{Rezumat}

Scopul lucrării a fost acela de a evidenţia gradul de promovare a jocurilor de mișcare în învățământul gimnazial, prin prisma ponderii acestora în cadrul componentelor structurale ale lecției de educație fizică. Cercetarea s-a desfăşurat pe parcursul anului şcolar 2014-2015. Pentru a surprinde diferite aspecte legate de utilizarea jocului de mişcare în lecţia de educaţie fizică, am efectuat 40 de fişe de observaţie la lecţiile desfăşurate în două unități școlare din Bacău la clasele V-VI. În urma rezultatelor obținute în lecţiile de educaţie fizică înregistrate pe baza fișelor de observație din cadrul cercetării, putem afirma că ponderea jocurilor de mișcare în conținutul structural nu a înregistrat valori impresionante și că valoarea lor formativă nu a fost exploatată la nivel superior. De aceea considerăm că ar trebui solicitate mai mult eforturile de imaginație și creativitate din partea cadrelor didactice de specialitate în spiritul folosirii acestor mijloace pe tot parcursul lecției.

\section{Introducere}

În condiţiile actuale, de restructurare a întregului proces de învăţământ și de reaşezare pe baze democratice, se impune cu deosebire optimizarea procesului instructiv-educativ la toate disciplinele din şcoală, deci şi a educaţiei fizice, atât în privinţa conţinutului activităţii cât şi a abordării metodelor și mijloacelor folosite. Este necesar să se utilizeze în lecţiile de educaţie fizică metode active care să ofere elevului oportunitatea de a participa activ şi conştient la procesul de formare.

Din diversitatea mijloacelor care stau la îndemâna profesorului de specialitate, jocul de mișcare este unul din cele mai atractive soluții pentru stimularea elevilor în practicarea exercițiului fizic. Subordonându-se obiectivelor instrucționale, prin conţinutul şi regulile sale, jocul de mișcare este un mijloc și o metodă ce trebuie promovat în cadrul de instruire la nivelul structural al lecției de educație fizică.

Jocul de mişcare se deosebeşte de celelalte mijloace ale educaţiei fizice deoarece înlesnește însuşirea şi consolidarea deprinderi motrice specifice în situaţiile mereu schimbătoare, (Acsinte, 2006) iar prezenţa elementului de întrecere în aplicarea lor presupune eforturi pentru realizarea cu succes a acţiunilor, ceea ce permite atât dezvoltarea calităţilor motrice cât şi a calităţ̧ilor morale ale elevului (Bonta, 2003). 
Considerând că, prin formă, conţinut şi efectele sale benefice, jocul de mişcare prezintă unele avantaje la nivelul elevilor din clasele gimnaziale, am optat pentru această cercetare.

Plecând de la convingerea că promovarea jocului de mișcare în cadrul componentelor structurale ale lecției de educaţie fizică, reprezintă o condiție sine qua non în îndeplinirea obiectivelor din curricula gimnazială, în condiții de atractivitate și accesibilitate, (Raţă \& Rață, 2008) se pot crea premisele motivaționale de atragere a elevilor în efectuarea exercițiilor fizice.

\section{Material și metode}

Scopul lucrării a fost acela de a evidenţia gradul de promovare a jocurilor de mișcare în învățământul gimnazial, prin prisma ponderii acestora în cadrul componentelor structurale ale lecției de educație fizică.

În realizarea cercetării de faţă am pornit de la următoarele ipoteze:

- Se presupune că jocul de mișcare este un mijloc accesibil şi la îndemâna profesorilor de specialitate pentru realizarea obiectivelor lecţiei de educaţie fizică la clasele din ciclul gimnazial.

- Identificarea ponderii utilizării jocurilor de mișcare în structura lecției de educaţie fizică din gimnaziu, constituie o premisă a unei intervenţii aplicative privind optimizarea procesului instructiv prin folosirea lor.

Cercetarea s-a desfăşurat pe parcursul anului şcolar 2014-2015. Pentru a surprinde diferite aspecte legate de utilizarea jocului de mişcare în lecţia de educaţie fizică, am efectuat 40 de fişe de observaţie la lecţiile desfăşurate în două unități școlare din Bacău, respectiv: Şcoala gimnazială nr. 19 „A. I. Cuza” şi Școala gimnazială nr. 10 din Bacău la clasele V-VI.

Conform etapelor de cercetare planificate, cercetarea observațională s-a desfășurat în perioada ianuarie - mai 2015 pentru a surprinde teme cât mai diversificate prevăzute în documentele de planificare.

Observaţiile întreprinse au vizat identificarea jocurilor de mișcare, ca mijloace pentru realizarea conținuturilor curriculare și îndeplinirea obiectivelor lecţiilor de educaţie fizică la clasele gimnaziale. În cadrul acestor observaţii am urmărit ponderea acestor mijloace care stau la îndemâna cadrelor de specialitate cu atât mai mult la nivelul elevilor de vârstă gimnazială (Raţă, 2008).

De mentionat este faptul că în observațiile organizate nu am luat în calcul alte tipuri de jocuri cu reguli particularizate precum cele de tip școală sau cu temă, specifice jocurilor sportive, sau alte mijloace care au prezentat caracter de emulație precum parcursurile aplicative.

Fişa de observaţie a cuprins conţinuturile specifice curriculei gimnaziale realizate prin tipuri de jocuri de mișcare, selecţionate după o documentare a materialelor bibliografice care au fost înserate pe verticală. În structura instrumentului folosit în cercetare au fost postate pe orizontală componentele structurale ale lecţiei de educaţie fizică, iar la intersecţia celor două axe au fost înserate datele înregistrate, respectiv numărul de lecţii înregistrat şi procentul corespunzător. 
Literatura de specialitate pune în evidenţă o gamă diversificată de modalităţi privind utilizarea jocurilor de mișcare ca modalități de îndeplinirea tuturor obiectivelor urmărite în lecţia de educaţie fizică la ciclul gimnazial. (Buscher, 2000; Pieper, 2001). Ele au un caracter polivalent putând fi utilizate cu mult succes în majoritatea componentelor structurale ale lecţiei în funcţie de obiectivele respective. „Ele contribuie la crearea unei bune dispoziţii de lucru, la înviorarea colectivului, atât din punct de vedere fizic cât şi psihic, precum şi la formarea anumitor calităţi morale şi fizice" (Băieşu \& Bârlea, 1969, citat de Dobrescu \& Constantinescu, 2006 ).

\section{Rezultate și discuții}

În urma observaţiilor efectuate la cele două instituţii de învăţământ preuniversitar, am constatat că pe perioada înregistrărilor la Școala gimnazială nr. 10 s-au înregistrat 45 de forme ale acestor mijloace folosite în perioada cercetată, cu o medie de 0,25 mai mare decât numărul celor întâlnite la Şcoala gimnazială nr. 19.

Analizând dinamica folosirii jocurilor de mișcare pe componentele structurale ale lecției, se constată că în primele două verigi s-au utilizat pentru organizarea colectivului de elevi, dar mai ales pentru pregătirea organismului pentru efort jocuri de atenție $(20 \%)$, jocuri cu comandă inversă $(7,5 \%)$, pentru exersarea capacităţii de percepţie $(12,5 \%)$ și cele pentru favorizarea relaţiei cu obiectul (10\%).

Deși, pentru influențarea aparatului locomotor, la niciuna dintre cele două școli nu au fost prezente tipuri concrete de jocurile de mișcare, în timpul complexelor de exerciţii de dezvoltare fizică armonioasă au fost promovate elemente de joc ce au stimulat emulaţia pentru execuții cât mai corecte, cu amplitudine mărită și o bună localizare a mișcărilor.

Rezolvarea obiectivelor verigilor de educare / dezvoltare aptitudinală a elevilor de clasele V - VI din cadrul cercetării au beneficiat de o diversitate de jocuri de mișcare. Ele au fost înregistrate în special pentru educarea vitezei $(17,5 \%)$, îndemânării $(22,5 \%)$ a dezvoltării forței $(17,5 \%)$ și într-un procent mai mic au vizat dezvoltarea rezistenței (10\%).

Altă componentă structurală a lecției care a stat în atenția profesorilor specialitate de a fi soluționată prin mijloace dinamice, mobilizatoare a fost veriga lecției de însuşirea și consolidarea deprinderilor aplicative (12,5\%), a conținutului motric din atletism (17,5\%), gimnastică $(20 \%)$ și jocuri sportive $(37,5 \%)$.

În multe lecţii cu teme ce au vizat formarea deprinderilor specifice unor ramuri sportive, au fost folosite structuri algoritmice din atletism, gimnastică, jocuri sportive sau alte forme de joc, precum cele cu temă, de tip şcoală, joc bilateral, precum și parcursuri aplicative.

Revenirea organismului la parametrii inițiali a fost rezolvată prin jocuri simple, de mică intensitate și cu caracter deconectant de tipul celor de atenție și de comandă inversă $(12,5 \%)$.

În urma cercetării observaționale se constată că jocurile promovate în 
structura lecțiilor nu au fost de mare complexitate, nu au presupus în toate cazurile folosirea obiectelor, a instalațiilor și a unor amenajări speciale. În schimb putem sublinia caracterul de emulație aplicat în majoritatea cazurilor și a precizărilor privind respectarea regulilor impuse pe parcursul desfășurării lor.

Pentru a evidenția ponderea utilizării jocurilor de mișcare în conținutul lecției de educație fizică din mediul gimnazial, am efectuat o analiză comparativă a rezultatelor studiului observațional la cele două unităti școlare cercetate pe componentele structurale. (Fig. 1)

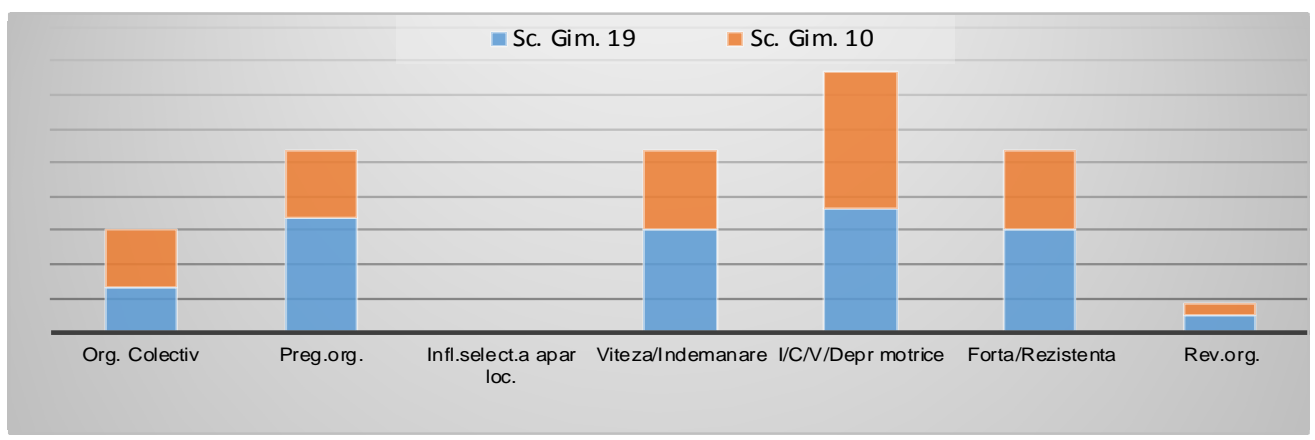

Figura nr. 1 Ponderea folosirii jocurilor de mișcare în structura lecției

În partea pregătitoare a lecţiei, la ambele școli s-au folosit jocuri pentru captarea atenţiei, ridicarea stării emoţionale şi jocuri pentru orientarea în spaţiu cu o mai uşoară şi gradată angajare a organismului în efort.

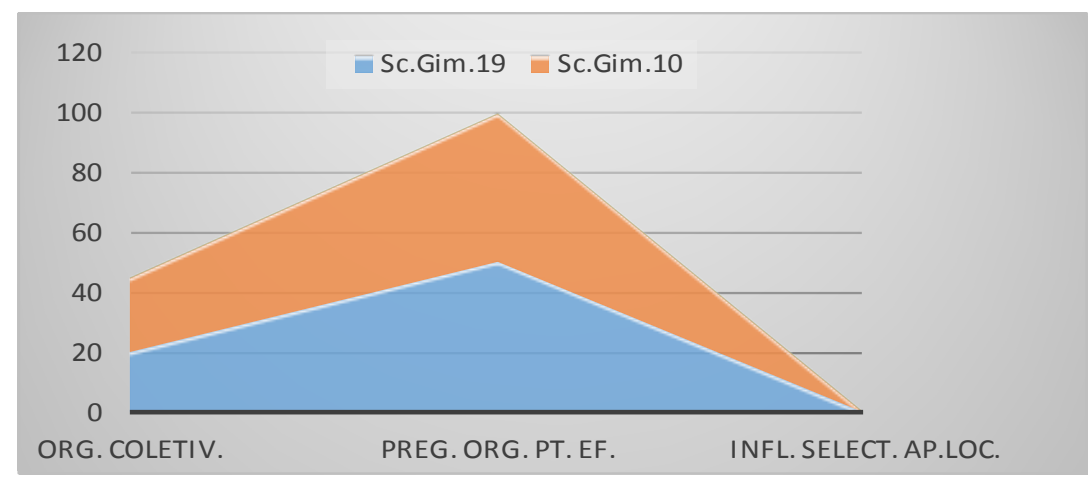

Figura nr. 2 Rezultatele observaţiilor obținute în primele 3 momente ale lecției

Dacă la ambele unităţi școlare, în 50\% dintre lecțiile înregistrate, au promovat jocul de mișcare pentru pregătirea organismului pentru efort, în prima parte structurală pentru organizarea colectivului de elevi, la Școala nr. 10 s-au folosit cu 5\% mai multe jocuri de mișcare pentru atingerea obiectivelor organizatorice. (Fig. 2) 
În partea fundamentală jocurile alese au condus la îndeplinirea sarcinilor lecţiei din această parte structurală, urmărind să formeze sau să consolideze deprinderile motrice de bază, specific unor discipline sportive, să contribuie la educarea sensibilităţii (ritm, echilibru) şi a calităţilor motrice de bază (viteză, îndemânare, forţă și rezistență).

În unele lecţii cu teme ce au vizat însușirea / consolidarea deprinderilor specifice unor ramuri sportive, au fost folosite structuri algoritmice din atletism, gimnastică, jocuri sportive sau alte forme de joc precum parcursuri aplicative, joc cu tema, joc şcoală, joc bilateral.

Analizând ponderea folosirii jocurilor de mișcare pentru învățarea / consolidarea / verificarea deprinderilor ramurilor de sport, se constată că dacă pentru cele specifice gimnasticii, ambele școli au manifestat interes egal $(20 \%)$, prima școală a excelat pentru deprinderile din jocuri sportive (25\%/15\%), iar pentru cele din atletism s-a schimbat balanța. (10\%/25\%) (Fig. 3)

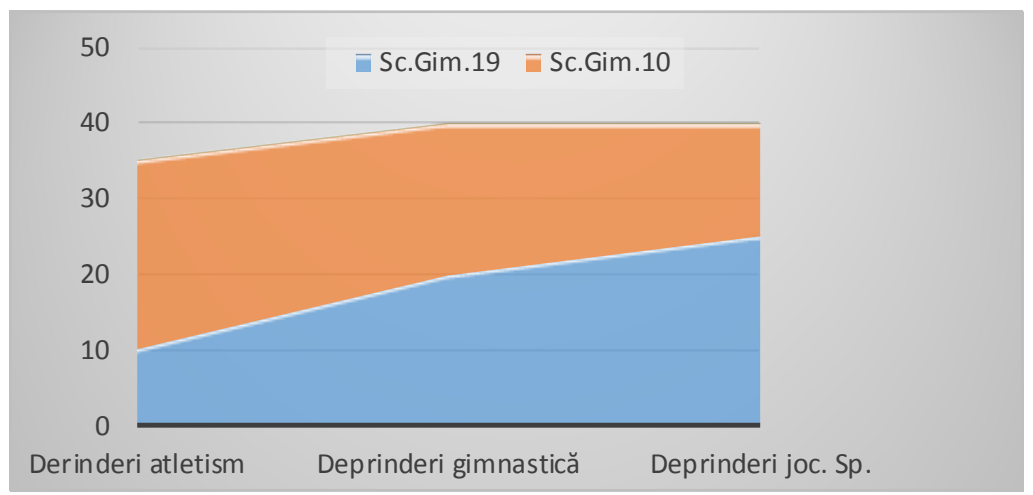

Figura nr. 3 Rezultatele observaţiilor obținute în verigile de deprinderi specifice unor ramuri de sport

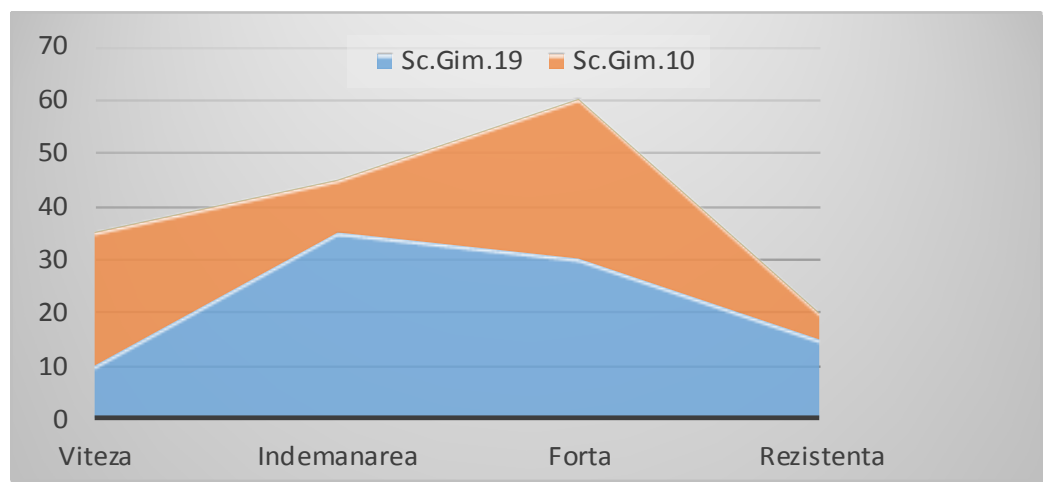

Figura nr. 4 Rezultatele observaţillor obținute în verigile de influențare aptitudinală 
Tot în această parte a lecției putem evidenția preocupări ale specialiștilor din cele 2 școli pentru rezolvarea obiectivelor privind educarea / dezvoltarea aptitudinilor psihomotrice. La Școala nr. $19 \mathrm{~s}$-au promovat jocurile de mișcare în mod prioritar pentru educarea îndemânării $(35 \%)$ și dezvoltarea forței $(30 \%)$ în timp ce la Școala nr. 10 au fost preocupări în acest sens pentru educarea vitezei (25\%) și dezvoltarea forței (30\%). La ambele centre de educaţie s-a optat pentru dezvoltarea rezistenței prin mijloacele specifice din ramuri sportive. (Fig. 4).

În ambele instituții școlare din cadrul cercetării efectuate, cadrele de specialitate nu au recurs la jocuri cu caracter liniştitor care să restabilească marile funcţiuni şi să capteze atenţia pentru partea de încheiere a lecţiilor de ducație fizică.

\section{Concluzii}

În urma observaţiilor realizate şi a rezultatelor înregistrate în fişele de observaţie s-au desprins următoarele concluzii:

Jocurile de mişcare constituie un mijloc important și accesibil cadrelor de specialitate prin care se realizează o parte importantă din sarcinile educaţiei fizice în vederea optimizării lecției de educație fizică, ceea ce confirmă prima ipoteză a lucrării.

Prin aplicarea judicioasă a jocurilor de mișcare există posibilitatea de a contribui în mare măsură la dezvoltarea calităţilor motrice (viteză, rezistenţă, forţă şi îndemânare) necesare în viaţă, formarea unor cunoştinţe utile, prin lărgirea sferei reprezentărilor despre lume.

În cadrul jocurilor de mişcare elementului de întrecere în majoritatea cazurilor presupune eforturi pentru realizarea cu succes a acţiunilor, ceea ce permite dezvoltarea spiritului de colectivitate, a calităţilor morale şi de voinţă.

Greutăţile întâmpinate de elevi în jocurile ce au în componenţa lor sărituri de pe aparate sau peste aparate le dezvoltă voinţa, perseverenţa şi atunci când aceste greutăţi sunt învinse, încrederea în forţele proprii.

Creşterea eficienţei lecţiei de educaţie fizică se poate realiza prin folosirea jocurilor de mişcare dacă acestea sunt bine selecţionate, organizate şi conduse cu tact de către profesorul de specialitate.

În urma rezultatelor obținute în lecţiile de educaţie fizică înregistrate pe baza fișelor de observație din cadrul cercetării, putem afirma că ponderea jocurilor de mișcare în conţinutul structural nu a înregistrat valori impresionante și că valoarea lor formativă nu a fost exploatată la nivel superior. De aceea considerăm că ar trebui solicitate mai mult eforturile de imaginație și creativitate din partea cadrelor didactice de specialitate în spiritul folosirii acestor mijloace pe tot parcursul lecției.

Ipoteza a 2 a cercetării a fost confirmată prin identificarea ponderii de utilizare a jocurilor de mișcare ca metodă și mijloc la clasele V - VI și a creat premisele unei intervenții aplicative care să evidențieze diversificatea influențelor acestora asupra elevilor și deosebite modalități de optimizare a obiectivelor lecției de educație fizică la ciclul gimnazial. 